\title{
Lord Lindsay's expedition to Mauritius in 1874
}

\author{
M. T. Brück \\ Institute for Astronomy, Royal Observatory, Blackford Hill, Edinburgh, EH9 3HJ, UK \\ email: mtb@roe.ac.uk
}

\begin{abstract}
An account is given of Lord Lindsay's lavishly equipped independent expedition to the Island of Mauritius in the Indian Ocean to observe the 1874 Transit of Venus. The expedition's secondary programme, the deriving of the solar parallax from observations of the minor planet Juno, is also described. This work proved a positive outcome of a generally disappointing event and brought about an important shift in the approach to the parallax challenge. The site on Mauritius where Lord Lindsay observed the Transit in 1874, now preserved as a National Monument, was the centre of celebrations during the Transit of 2004.
\end{abstract}

\section{Dun Echt Observatory Transit plans}

The Transit of Venus in 1874 was anticipated as "probably the most important astronomical event of the century" (1). Seventy-five observing stations were distributed worldwide, from France, Russia, Germany, the Netherlands, Great Britain, the United States, and their various dependent colonies. Of these, Britain sent eight teams of observers on expeditions which were centred on five locations - Egypt, the Hawaiian Islands, the Indian Ocean, New Zealand and the remote southern Kerguelen's Island - and were joined in collaboration by India, South Africa and Australia. The British effort was co-ordinated at the Royal Observatory at Greenwich, and masterminded with military efficiency by the Astronomer Royal Sir George Airy - "a generalship quite unparalleled in the annals of Science" (2).
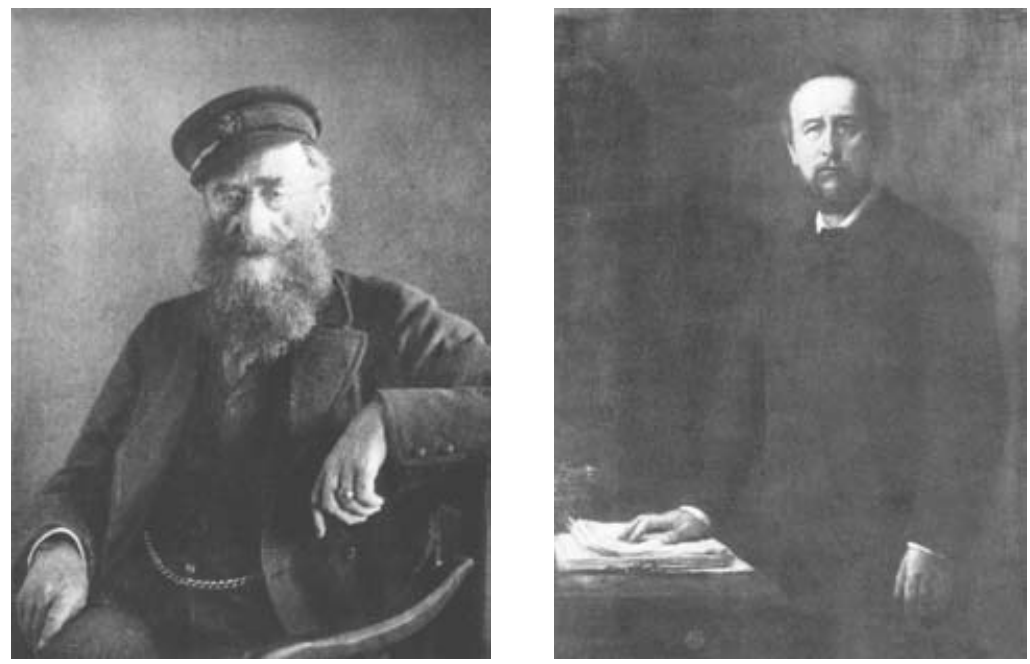

Figure 1. (left) Lord Lindsay, 26th Earl of Crawford and Balcarres and (right) (Sir) David Gill, portrait by George Reid 
One British expedition did not conform to the national plan - Lord Lindsay's privately funded expedition to Mauritius in the Indian Ocean(3). Lord (James Ludovic) Lindsay (later 26th Earl of Crawford) (Fig. 1), a talented amateur astronomer, engineer and photographer, founded an observatory on the family's country estate at Dun Echt, near Aberdeen, Scotland, which functioned successfully from 1872-92(4) and survived as a major component of the Royal Observatory Edinburgh(5). Lindsay's immediate ambition, when he began to make his plans in 1872, was to observe the approaching Transit of Venus, and preparations for the Transit went hand in hand with the furbishing of the new observatory. He recruited as his collaborator David Gill of Aberdeen (Fig. 1), a watchmaker by profession and a passionately enthusiastic and able amateur astronomer. Together they set about acquiring a variety of instruments, with particular reference to the needs of the Transit. In contrast to the official British expeditions, which were uniformly equipped with equatorial telescopes, Lindsay and Gill went their independent way. They decided that their principal instrument should be one which had been ruled out of the British plans - a heliometer, the choice of the official German and Russian expeditions. Lindsay sent Gill to St Petersburg to take advice from the great Otto Struve at the Pulkovo Observatory, after which they both attended a special Transit-planning meeting of the German Astronomische Gesellschaft, of which Struve was President, in Hamburg. There they met leading German and Russian astronomers, including Arthur Auwers of the Prussian Academy of Science, prime mover of the German Transit effort and Secretary of the German Transit Commission(6), who became Gill's close friend and later collaborator.

The Dun Echt heliometer (Fig. 2), constructed by the firm of Repsold of Hamburg, was of 4 inches $(10 \mathrm{~cm})$ diameter, and was to be handled specifically by Gill who familiarised himself thoroughly with its use at Dun Echt over many months. Preparations did not stop there. Lindsay also acquired a long focus (40 foot or $12.2 \mathrm{~m}$ ) solar horizontal telescope, fed by a Foucault siderostat (Fig. 3), for photography of the Transit in the manner favoured by the American astronomers; and a 6 -inch $(15 \mathrm{~cm})$ telescope equipped with a double-image micrometer for visual observations of the Transit as used by the official British expeditions. Together with a splendid portable transit theodolite by Troughton and Simms (Fig. 4), chronometers, and auxiliary apparatus, the Dun Echt expedition was, in the words of Agnes Clerke, "the epitome of modern resource and ingenuity" (7).

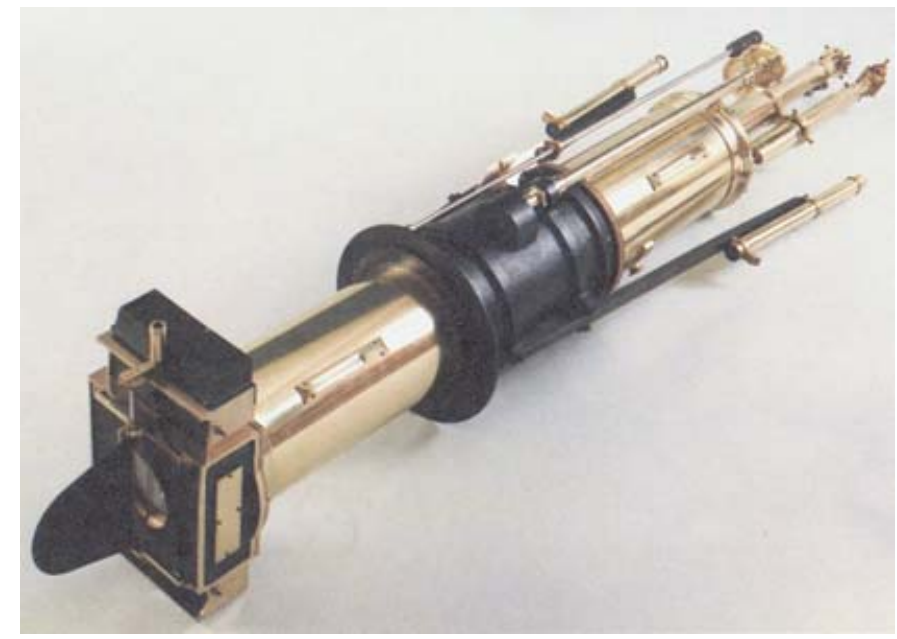

Figure 2. The Dun Echt heliometer (Royal Observatory Edinburgh) 


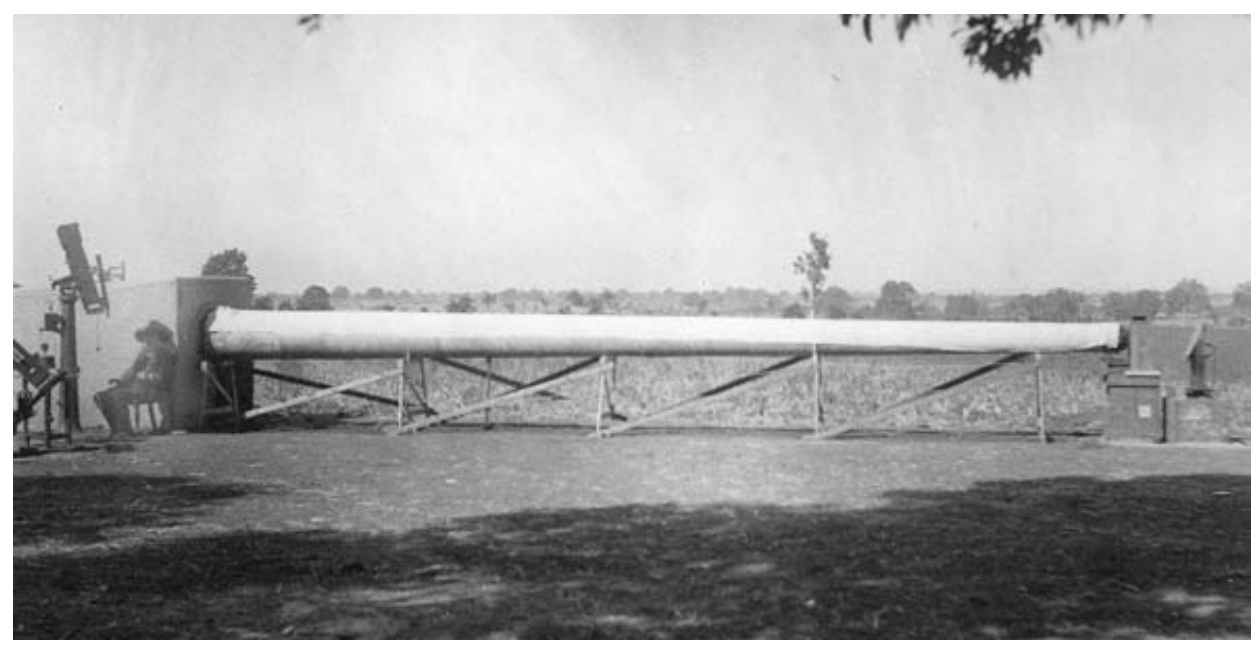

Figure 3. The 40-foot solar telescope, with Ralph Copeland, at the eclipse expedition to Russia in 1887

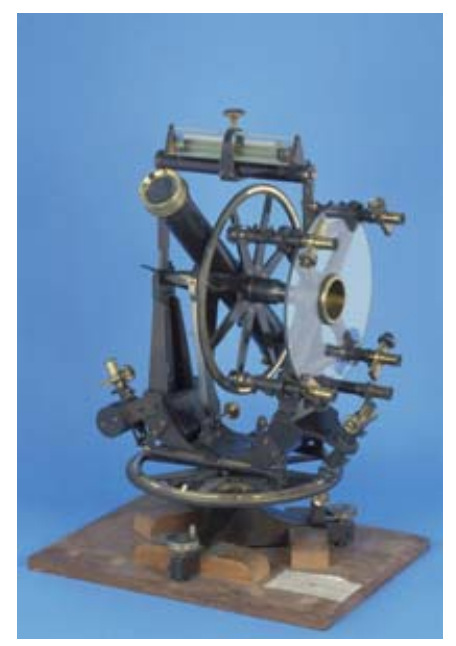

Figure 4. Transit theodolite (Royal Museums of Scotland)

\section{The Transit}

Lord Lindsay travelled to Mauritius on his yacht, the Venus, with a crew of 22 men, accompanied by the astronomer Ralph Copeland, on leave from his post at Dunsink Observatory, Dublin, his photographer Henry Davis and the ship's surgeon. The "wearisome voyage" around the Cape took longer than anticipated due to unfavourable weather almost four months, from July 9 to November 2. David Gill, bearing 50 chronometers, travelled separately by ship via the Suez canal, and reached Mauritius on 4 August, where he was welcomed by his countryman Charles Meldrum(8), Director of the Royal Alfred Observatory (a meteorological observatory) at Pamplemousse who also planned to observe the Transit. The observatory carpenter from Dun Echt, with domes and huts, travelled with Gill, and all building work was ready by the time Lord Lindsay and his companions sailed in. A resident of the island, Eduard de Chazal, offered the party a 


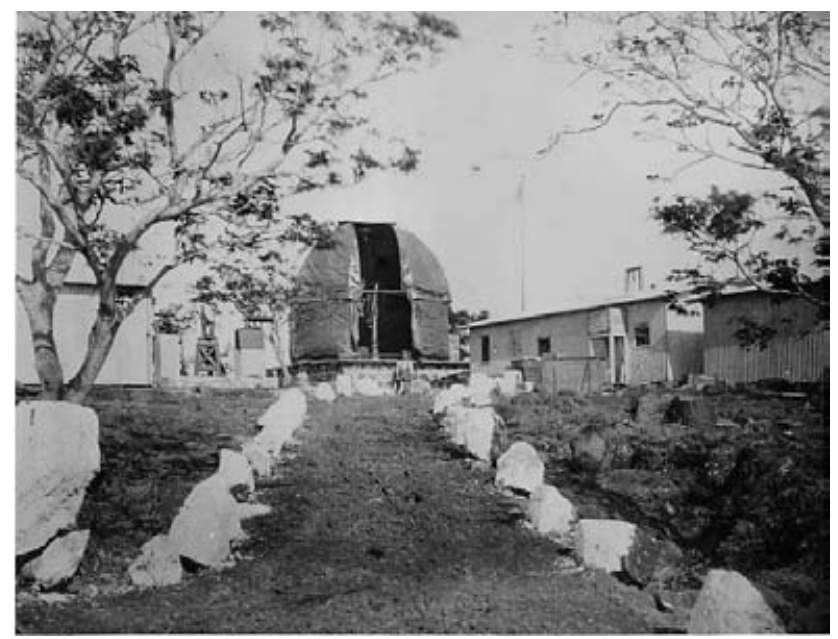

Figure 5. The expedition's observatory at Belmont (Mauritius Transit of Venus 2004 Committee)

site on his estate at Belmont, sixteen miles from Port Louis (latitude $20^{\circ} \mathrm{S}$ ), and put his house at the disposal of the astronomers for the duration of their operations (Fig. 5).

The crucial day of the Transit began cloudy, but cleared up sufficiently for a range of observations to be made with the heliometer, and a large number (270) of photographs of the sun to be obtained(9). (None of the photographs survives in the Dun Echt archives at the Royal Observatory Edinburgh). The material was sent back to Dun Echt for reduction, but never published: the overall results worldwide were disappointing.

\section{Parallax of Juno}

The Dun Echt astronomers, however, had another string to their bow. As well as observing the Transit, Gill planned a hitherto untried method to obtain the solar parallax - the measurement of the position of a minor planet (asteroid) relative to the stars in the evening and in the morning. The "diurnal" method of observing the parallax of a planet, and hence of the sun, had been suggested as far back as 1857 by G.B. Airy, but had not previously been put into practice. Instead of observing the planet from widely separated positions on the surface of the earth, the astronomer observes it from the same location after an interval of many hours, allowing the rotation of the earth to provide the baseline for parallax. This requires to be done when the planet is in or near opposition, the observations being made in the evening and again in the morning.

The idea of using a minor planet for parallax work originated with J.G.Galle of Berlin, who in 1872 pointed out that a minor planet, though more distant, had the advantage of a star-like appearance, allowing its position to be more precisely determined. He attempted it with the minor planet Flora at its opposition in October 1873, with the cooperation of a number of observatories, including Dun Echt, and corresponded with Gill on the subject(10). As Lord Lindsay explained: "The total parallactic displacement is very considerably less than in the case of an opposition of Mars, or a Transit of Venus, but we believed that the great accuracy attainable in the heliometric measurement of the distance of two minute points of light would more than compensate for this defect" (11). The minor planet chosen was Juno, which was in opposition one month before the Transit of Venus, on 5 November 1874. Lindsay and Gill prepared a list of comparison stars, 


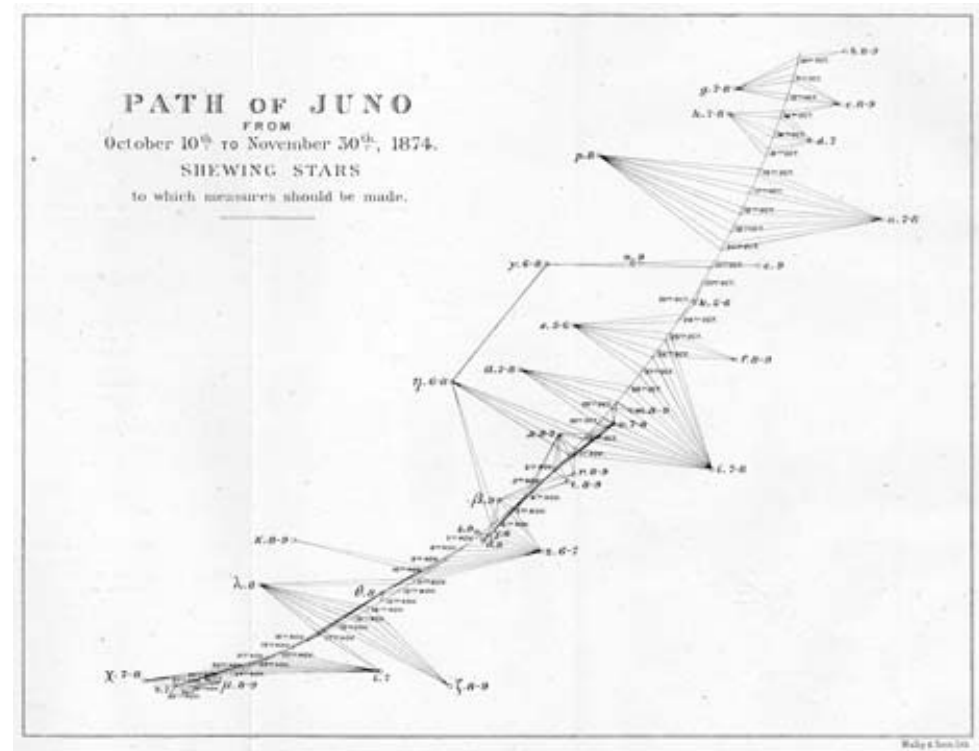

Figure 6. Path of Juno at opposition 1874 (Monthly Notices of the Royal Astronomical Society 43, 1874)

against which Juno's position would be measured with the heliometer over a period before, during and after opposition (Fig. 6)(12). Gill was installed in Mauritius in good time, but the heliometer, which was transported by yacht, unfortunately arrived late, and Gill's observations began only on 12 November, continuing until 30 November, a total of fifteen nights. The span was enough, however, to establish the method and provide a result distinctly more reliable than the Transit of Venus could deliver. The procedure was also original, in that it combined for the first time the diurnal method with the use of a minor planet.

Gill's reductions, laid out in a 200 page paper, gave a value for the solar parallax of 8. ' $77 \pm 0$ ". 04 (probable error)(13). The experience gave him a "conviction that very powerfully influenced a considerable part of my future work"(14). Forgoing his salaried post at Dun Echt, he embarked on his next major and highly successful undertaking - the observation by the diurnal method of the opposition of Mars from the Island of Ascension in 1877, again using the heliometer, his favourite instrument. Thus, while the results of the actual Transit were universally disappointing, the Dun Echt expedition was by no means a wasted effort. Contrary to the pre-transit belief that "the coming observations are to serve astronomers until 2004"(15), the Juno series of observations, described in retrospect as "probably the most important result of all the many costly Transit of Venus expeditions" (16), initiated an improved way of finding the solar parallax(17). Nor did the instruments acquired for the Transit become redundant. Lord Lindsay's heliometer was used for Gill's observations of Mars, and the 40-foot solar telescope was employed by Copeland on three solar eclipse expeditions and for solar spectroscopy at Dun Echt and at the Royal Observatory Edinburgh.

\section{Geodesy}

The second substantial piece of work of the expedition was the determination of longitudes, not only at Mauritius but at various locations in the Indian Ocean. Telegraphic 
communication existed only at a few centres: astronomers relied on carrying the time with them by chronometer, and comparing chronometers with those at other stations. The longitude differences within Mauritius were established - between the Dun Echt site and those of Meldrum's observatory and of the German one at Solitude, a site south of Lindsay's where the observers M. Low and C.F. Pechüle also used a heliometer(18). For comparison with the British site at the neighbouring island of Rodriguez, the chronometers were transported by sea, a journey of 14 hours, and were also compared with those of the Dutch astronomers who had a station on the island of Reunion, and with the French station on St Paul's(19). Gill spent a month travelling through the Indian Ocean, linking also the Seychelles, and reaching Aden, Suez and and Alexandria, which were connected to Berlin by telegraph. In the last part of the chain, Gill had the cooperation of his German friend Auwers who was still at his own Transit station in Egypt. The exercise sparked Gill's abiding interest in geodesy.

\section{Sequel}

Over and above its scientific value, the Mauritius expedition was a springboard in the careers of Lord Lindsay's two colleagues. The parallax observation of Juno, repeated for Mars three years later, propelled Gill in 1879 to distinguished eminence as H.M. Astronomer at the Cape of Good Hope: the first to bring the good news of his appointment was Lord Crawford, "my former chief - an ever-true and loyal friend"(20). Ralph Copeland succeeded Gill at Dun Echt, and in due course, when Lord Crawford came to the rescue of Edinburgh's ailing Royal Observatory, became third Astronomer Royal for Scotland. "I cannot help feeling" said the present Earl of Crawford on the centenary of that event, "that he [his great grandfather] included in his gift his astronomer, his friend Dr Copeland" (21).

\section{Mauritius revisited 2004}

Before the Dun Echt astronomers dismantled their station on Mauritius in 1874, their host Monsieur de Chazal, made a generous gesture, which Lord Lindsay put on record in his Report of the expedition:

I wish now to express my feelings of gratitude towards those who were so kind to me and mine during my three months' stay on their island. Towards Mons. de Chazal and his family I shall ever bear the warmest feelings of regard and sympathy. He most generously placed at my disposal, during my stay, the house and buildings of his estate at Belmont in the district of Poudre d'Or, in the north-east part of the island, about sixteen miles from Port Louis. When prostrated by fever, had I been his own son I could not have been cared for with more tenderness. Not content with thus ministering to the wants of the present, he executed a gift to the Government of the site upon which my observatory was placed, considering that it would be well, in the interests of science, that the actual spot on which the observations were taken should be preserved, and should not share the fate of the Base measured in 1753-54 by the Abbé La Caille, which unfortunately cannot now be identified(22). On this ground I claim for Mons. de Chazal the gratitude of future generations of astronomers and geodetecists.(23)

On de Chazal's death a few years later, Lord Lindsay, then President of the Royal Astronomical Society, paid further tribute to him at a meeting of the Society, as "a gentleman who, though not a Fellow of the Society, had done very much for her science, who had placed his observatory in the hands of Her Majesty's Government, and whose interest in the work was only equalled by his kindness during Lord Lindsay's illness." (24) 
M. de Chazal's wish has been honoured by the Government of Mauritius. The site at Belmont, where Lord Lindsay's observatory stood, has been cleared and its foundations revealed. It is now designated a National Monument (Fig. 7), and a special committee celebrating the 2004 Transit of Venus included in its festivities a commemoration of that historic expedition and the naming of Lord Lindsay Avenue. Greetings were also received from Dr. Adrian Russell and Prof. James Dunlop, respectively Director of the UK Astronomy Technology Centre and Head of the Institute for Astronomy, University of Edinburgh. These two institutions now occupy the site of the the Royal Observatory Edinburgh. The Transit of 8 June 2004 was observed by thousands of schoolchildren and adults on the actual site of the 1874 expedition. Among official guests taking part in that happy event (Fig. 8) was the Honourable Alexander Lindsay, direct descendent of his namesake of 1874 .

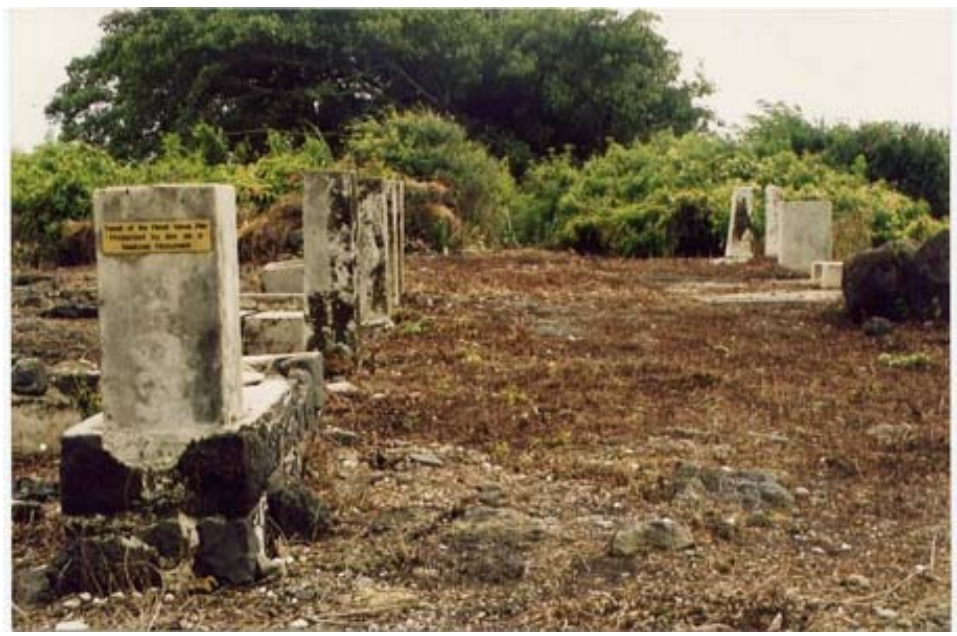

Figure 7. Plaque on the walls of Lord Lindsay's observatory, now a National Monument

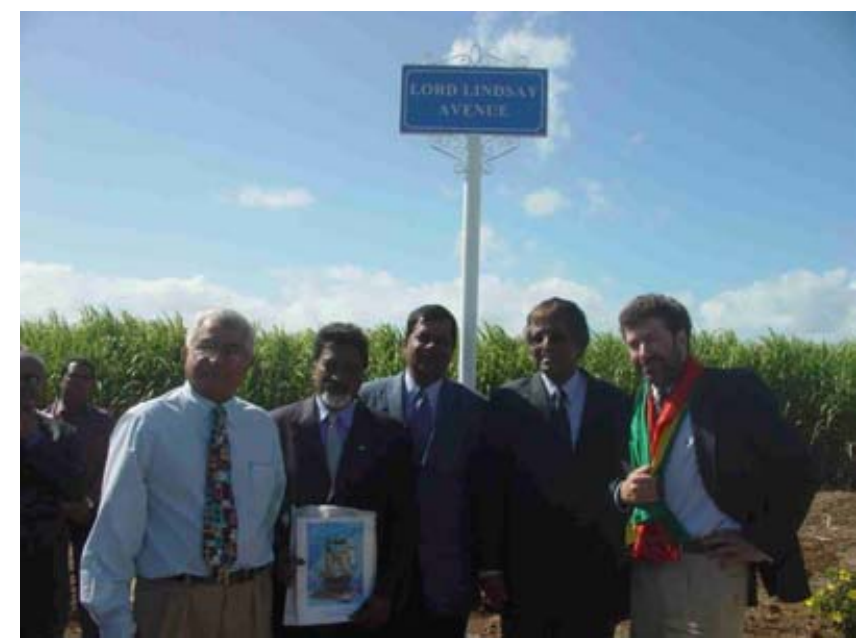

Figure 8. Celebration of the Transit of Venus 2004 on the 1874 site. From left to right: Cader Kalla, Chairman of the Mauritius Museum Council; Motee Ramdass, Minister of Art and Culture; Dr Jhurry, a Representative of the District Council; Anil Gayan, Minister of Tourism and Leisure and Alexander Lindsay 


\section{Acknowledgements}

My warm thanks are due to Karen Moran, librarian at the Royal Observatory Edinburgh, and also Jason Cowan and Clive Davenhall for their skilled help in preparing the manuscript for publication. Marie-Jose Martial-Craig, secretary of the National Transit of Venus 2004 Committee, Government of Mauritius, has kindly provided the photographs and press reports of the 2004 celebrations. Her generous help and cooperation is quite particularly appreciated.

\section{References}

(1) George Forbes 1874. The Transit of Venus. London: Macmillan and Co. Forbes, Professor of Natural Philosophy at the Andersonian University, Glasgow, was in charge of the British Transit observations in Hawaii.

(2) George Forbes ibid.

(3) A brief account was presented to the Archives Committee of the International Astronomical Union in Sydney 2003: M.T. Brück. 'Lord Lindsay's Transit of Venus expedition to Mauritius 1874.' ICHA Newsletter 5, 24; Journal of Astronomical History and Heritage 6, 37.

(4) H.A. Brück 1992. 'Lord Crawford's Observatory at Dun Echt 1872-1892.' Vistas in Astronomy 35, 81-138.

(5) In 1888 Lord Crawford made a gift of the entire contents of his observatory, including its priceless Crawford Library, to the nation to furnish Edinburgh's new Royal Observatory which opened officially in 1896. H.A. Brück 1983. The Story of Astronomy in Edinburgh, Edinburgh; H.A. Brück 1992. op. cit. (4); M.S. Longair, H.A. Brück, 29th Earl of Crawford and M.T. Brück 1988. 'Centenary of the Royal Observatory Edinburgh 1888-1988.' Vistas in Astronomy 32, 201-214.

(6) Hilmar W. Duerbeck 2004. 'The German Transit of Venus expeditions of 1874 and 1882.' Journal of Astronomical History and Heritage 7, 8-17.

(7) Agnes M. Clerke 1902. A History of Astronomy during the Nineteenth Century, p 234. (Reprint edition, Decorah: Sattre Press 2003).

(8) Dictionary of National Biography. (Compact Edition) 1975. Oxford University Press.

(9) David Gavine 1982. Astronomy in Scotland. Ph.D thesis, Open University.

(10) J.G. Galle. Letter to Gill, addressed from Breslau, 1874 June 28. Dun Echt archives, Royal Observatory Edinburgh. Juno's distance from the Earth at opposition was .67 AU, compared with .52 for Mars.

(11) Lord Lindsay 1877. Dun Echt Observatory Publications, Volume 2, Introduction.

(12) Lord Lindsay and David Gill. 1874. Monthly Notices of the Royal Astronomical Society 34, 279-300.

(13) Lord Lindsay and David Gill 1877. Dun Echt Observatory Publications, Volume 2, 1-212.

(14) David Gill 1913. A History of the Cape Observatory, H.M.S.O, p36.

(15) George Forbes op. cit. (1).

(16) Obituary of Lord Crawford. Nature, 1913 February 13.

(17) See Steven J. Dick 2004. 'The American Transit of Venus Expeditions of 1874 and 1882,' this conference.

(18) H. Duerbeck op. cit. (6), p11.

(19) Lord Crawford 1885. 'Mauritius Expedition 1874: Determinations of longitude and latitude.' Dun Echt Observatory Publications, Volume 3.

(20) David Gill 1913. op. cit (14), p39.

(21) 29th Earl of Crawford, reference (5).

(22) Brian Warner 2002. 'Lacaille 250 years on.' Astronomy and Geophysics 43, pp2.25-2.26.

(23) Lord Lindsay 1877. Dun Echt Observatory Publications, Volume 2. Preface.

(24) Lord Lindsay 1879. Observatory 3, no 25. p1. 